\title{
SURVIVAL CAUSAL PATTERNS OF SOCIAL AND COMMERCIAL ENTREPRENEURIAL INITIATIVES IN SPAIN
}

\author{
Lorenzo REVUELTO-TABOADA $\mathbb{1 D}^{*}$, Ana REDONDO-CANO®D, \\ Francisco BALBASTRE-BENAVENT \\ Departament of Business Management, University of Valencia, Valencia, Spain
}

Received 27 July 2020; accepted 26 February 2021

\begin{abstract}
This research aims at analysing the influence of a holistic configuration of factors related to industry and the characteristics of the entrepreneur and the business, on the survival of social and commercial entrepreneurial initiatives in both, new and consolidated companies. The sample ranges from 2,851 to 2,109 firms, according to the period considered, and has been obtained from the reports of the projects submitted to the Assistance Programme to Young Entrepreneurs, promoted by the Valencian Institute of Youth. Other sources of information have been the Institute's own reports and the Chambers of Commerce. A configurational analysis is performed using the Fuzzy-Set Qualitative Comparative Analysis. The results obtained show that there is no necessary condition by itself and that there are several sufficient solutions that explain a considerable percentage of survival cases. They also show how the solutions vary significantly and, consequently, the relevance of the different causal antecedents, when the company acquires greater maturity.
\end{abstract}

Keywords: entrepreneurship, firm survival, social firms, commercial firms, causal patterns, fuzzyset Qualitative Comparative Analysis.

JEL Classification: M13, L26, J08.

\section{Introduction}

New ventures play an important role in economic growth, job creation and innovation; but show great failures rate, especially in their first years of operation. Consequently, the analysis of business survival and the factors that may help to explain it have been, for decades, a relevant research line of management studies. Many authors consider survival as one of the key indicators to determine the success of a company (Brüderl \& Schüssler, 1990; Haber \& Reichel, 2005).

The literature identifies three sets of variables that contribute to explain the survival of newly created companies: the characteristics of the entrepreneur; the characteristics of the

*Corresponding author. E-mail: lorenzo.revuelto@uv.es

Copyright $\odot 2021$ The Author(s). Published by Vilnius Gediminas Technical University

This is an Open Access article distributed under the terms of the Creative Commons Attribution License (http://creativecommons. org/licenses/by/4.0/), which permits unrestricted use, distribution, and reproduction in any medium, provided the original author and source are credited. 
business and organisation; and the characteristics of the environment (Franco \& Haase, 2010; Salder \& Bryson, 2019; Schutjens \& Wever, 2000). The vast majority of previous studies have focused on analysing the separate impact of these variables on survival using multivariate statistical techniques. However, taking into account that entrepreneurship is a complex phenomenon and survival, in particular, can be explained by different combinations of variables, the use of Qualitative Comparative Analysis can be considered a useful option. This method admits that different antecedent conditions (equivalent to variables in statistical analysis) can lead to the same result and that the causal configurations (combination of conditions) that explain a given result (i.e., survival) may not coincide with those that explain the opposite result (i.e., closure) (Fiss, 2011; Woodside \& Zhang, 2013).

The study of survival in newly created companies is especially important, since although they tend to have the support of public institutions (Chandra \& Wong, 2016), they generally have higher mortality rates than those consolidated entrepreneurial initiatives (Brüderl \& Schussler 1990; Headd, 2003; Simón-Moya \& Revuelto-Taboada, 2016). The combinations of causal factors related to survival will vary over time, as the relative importance of the different factors in the different stages of life of the company changes. In this vein, it would be interesting to go deeper into the study of survival of new firms versus survival of consolidated firms, and analyse whether the causal combinations that explain this result differ or not.

Bearing in mind the above, the main objective of this research is to analyse the causal complexity underlying the survival of entrepreneurial initiatives, both in new and consolidated firms, that is, survival in the short and medium term. The study focuses on two groups of causal antecedents, those linked to the characteristics of the entrepreneur and the characteristics of the business although the sector (manufacturing/service), frequently used as control variable, is also considered.

To achieve this goal, the work is structured as follows. First, it is shown the theoretical framework where the main conditioning factors of survival are reviewed; subsequently, a series of propositions to be validated are defined. The following section contains the methodology that justifies the suitability of the Qualitative Comparative Analysis, specifically the fuzzy-set Qualitative Comparative Analysis, and the steps followed for its application. Likewise, the aspects related to the sample and information gathering are included. Later, the results of the necessity and sufficiency analysis are collected. Finally, the conclusions, practical implications and future lines of research are presented.

\section{Theoretical framework}

Entrepreneurship is a phenomenon that has a great impact on the generation of employment and wealth in a country. For this reason, studying in depth the factors that influence the success and survival of companies has aroused great interest among academics (Carlsson et al., 2013). This research focuses particularly on two types of factors: a) those related to the characteristics of the entrepreneur, where training and related experience, as well as motivation to undertake have been extensively analysed; b) and those linked to the organisation and the business, availability of resources (both financial and human), purpose of the firm (social versus commercial) and industry. 


\subsection{The characteristics of the entrepreneur}

The training and experience of the entrepreneur have been shown in the literature as substantial elements to explain the survival of business ventures (Eliakis et al., 2020; Headd, 2003; Millan et al., 2012). The specific or related training, that is, the one that focuses on processes, technologies or relevant products in the sector, allows the entrepreneur to better detect the needs of his target population, use more efficiently the resources he owns and reduce costs (Ribeiro-Soriano \& Castrogiovanni, 2012; Van Praag, 2003). Kurczewska and Mackiewicz (2020, p. 427) state that "pursuing variety in education and accumulating numerous and diverse experiences is key for both business start-up and its (long-term) continuation".

Regarding the experience of the entrepreneur in the sector and/or as an entrepreneur, it should be noted that most of the authors agree that it is a relevant factor in relation to the success of the entrepreneurship (Millan et al., 2012; Simón-Moya \& Revuelto-Taboada, 2016). Nevertheless, there are studies that indicate that, in the case of self-employment, there may be a negative effect of previous experience on the survival of the company (Roberts et al., 2013).

The third variable taken into consideration, the motivation that leads to entrepreneurship, makes us differentiate necessity entrepreneurs from opportunity entrepreneurs (Martínez-Rodriguez, et al., 2020; Van Praag, 2003). The former are those that have no special interest in the business itself and entrepreneurship is a way to avoid inactivity, in the absence of job opportunities. On the other hand, the latter are vocational entrepreneurs who start their activity when they detect a business opportunity and seek autonomy and independence in their work.

The results of different studies agree that opportunity entrepreneurships survive longer and obtain better results (Ho \& Wong, 2007; Rico-Belda \& Cabrer-Borrás, 2018). The greater capacity for innovation and commitment of these entrepreneurs become important factors in explaining these results (Ho \& Wong, 2007; El Harbi \& Anderson, 2010). By contrast, necessity entrepreneurs seek income urgently and have limited investment capacity, so they tend to set up smaller companies, both in terms of staff and investment. Also, these entrepreneurs tend to have a lower level of training than opportunity entrepreneurs (Kelley et al., 2010). This would explain, at least partially, the differences in the survival rates between both types of entrepreneurs. In this sense, Millan et al. (2012) show how the creation of companies by entrepreneurs that come from a situation of unemployment (necessity entrepreneur) increases the probability for them of re-entering the group of unemployed people again. Even when these entrepreneurs have training and experience, their ventures have a shorter survival period as transition to entrepreneurship is usually a temporary solution to joblessness (Nyström, 2020).

\subsection{The characteristics of the company}

The availability of resources, both financial and human, are among the most studied explanatory variables of survival. The infant industry theory explains the implications of the liability of newness (Aghion, 2011) on survival, indicating that young companies face up to entry barriers that may precipitate their failure. One of the main barriers derives from the difficulty to access resources, either capital (Kerr \& Nanda, 2011) or specialised human 
resources, since, in general, this kind of firms has scarce resources to acquire them and/or time to develop them internally.

On the other hand, new firms need some time to develop new roles and relationships with their environment (consumers, suppliers, beneficiaries, funders, and other public and private institutions), as well as to gain legitimacy (Stinchcombe, 1965). Likewise, their lesser knowledge of the environment can lead them to trial and error processes, which may have negative effects on their efficiency levels.

Most of the startups also drag a second burden, namely, the liability of smallness. This aspect becomes a disadvantage for young firms compared to established companies, especially when the latter enjoy both economies of scale and economies derived from the experience effect. Also and related to the size of the firm, two of the factors that show a more consistent and positive relationship with business success and survival are the number of employees and initial capital (Agarwal \& Audretsch, 2001; Headd, 2003; Mas-Verdú et al., 2015).

The purpose of the company (social vs. commercial) can also affect its survival as the specialist literature suggests, although the results are conflicting somehow. Some studies reveal that there are no significant differences in the levels of survival in the first years of life between social and commercial firms (Simón-Moya et al., 2012). Contrarily, other research shows that social firms obtain higher levels of survival (Denny, 2014; Gimmon \& Spiro, 2013). In many cases, professional activity in social firms constitutes a secondary activity in the collaborator's professional life (Nicolás \& Rubio, 2012). Furthermore, social entrepreneurs do not act necessarily motivated by material or monetary remuneration (Guzmán \& Trujillo, 2008); instead, they are inspired by a prosocial motivation (Grant, 2008; Penner et al., 2005), more altruistic. This motivation may make them preserve the firms, helped by grants and voluntary work, in situations in which a commercial entrepreneur would give up without hesitation.

However, social enterprises generally face the problem of scarcity of resources (Fournier, 2011; Guzmán \& Trujillo, 2008). Nevertheless, entities more inclined to finance social firms have appeared, and some governments have launched some specific programs for financing social entrepreneurship, although their impact is limited (Nicolás \& Rubio, 2012). Regarding human capital, in general, social enterprises cannot offer competitive salaries, while employees' personal satisfaction of fulfilling a social mission is one of the main keys to retaining talent.

Also, industry becomes an important factor affecting firm's survival in its first years of life. The necessary investments as well as entry and exit barriers are usually higher in the case of manufacturing companies, which could affect their survival. On the other hand, service firms (particularly professional service firms) are very dependent on the experience and knowledge of the promoters, and less on the initial capital investment (Stewart, 2018). Anyway, given its influence on the analysis of survival, this variable has been frequently used as a control variable.

Considering all the arguments exposed above, it could be observed, on the one hand, that there are a number of factors that can help explain the success and/or survival of entrepreneurial initiatives. On the other hand, the literature review reveals that research studying these factors obtain contradictory conclusions, as these factors may generate positive, negative and/or neutral effects on survival. In this sense, the literature on entrepreneurial 
bricolage (Senyard et al., 2014) highlights the ability of certain entrepreneurs to launch, despite budget constraints, innovative projects or recombine apparently obsolete or of little use resources, reaching unexpected advantages as a result (Garud \& Karnoe, 2003). In short, the knowledge and skills of the entrepreneur (Di Domenico et al., 2010) along with his creativity (Raine \& Pandya, 2019) and, of course, resilience (Chadwick \& Raver, 2020) can lead him to success where others failed with greater initial endowment of resources.

It should also be noted that as far as firms have more resources, they are more likely to survive in the initial period and consolidate. Resources can allow them to remain active the time necessary to identify the appropriate organisational routines, learn to collaborate with different internal and external stakeholders, gain legitimacy and develop the knowledge and skills necessary to adopt a suitable strategy and implement it successfully, as well as to adapt it, if necessary, depending on the evolution of the relevant environmental variables.

Under these circumstances and in relation to survival, both in the short and long term, the analysis of the influence of a holistic configuration of factors (instead of a relationship between factor and result) can help us to better understand the combination of factors that, in each case and moment of time, explains firms' survival. Thus, treating individual cases as holistic configurations allows us to show the complexity of how different elements are combined to produce a certain result (Dimov, 2017, p. 215).

Taking the above-mentioned arguments as a starting point, the following propositions can be derived:

P1. None of the determining factors or causal patterns considered, relative to the characteristics of the entrepreneur and the company or the kind of industry is, by itself, a necessary condition for the survival of companies, whether these are new or consolidated firms.

P2. Different combinations of the causal factors considered can constitute a sufficient condition for the survival of companies, whether these are new or consolidated firms.

P3. The combinations of the causal factors that constitute a sufficient condition for survival may vary between new and consolidated firms.

\section{Methodology}

\subsection{Information gathering and sample}

Authors created a database in collaboration with the Service of Programmes Management and Planning of the Valencian Institute of Youth, within the framework of the Aid Programme for Firms Created by Young Entrepreneurs. Initially the database had a total of 3,477 firms, but those records in which there were lost values for the analysed variables were eliminated. Firms were created between 2000 and 2005 by entrepreneurs under the age of 30, alone or in collaboration with others over that age, provided their participation was a minority. The information was obtained from the reports of the projects submitted to the programme. Survival information was gathered from the monitoring of the companies created, based on the databases of the Chambers of Commerce of Alicante, Castellón and Valencia.

The measurement of survival has been based on the distinction made by the Global Entrepreneurship Monitor between new firms (companies that exceed 3 months and achieve 42 months of activity) and consolidated firms (companies that exceed 42 months of activity). 
With all this, the sample consists of 2,851 companies in the case of new firms and 2,109 in the case of consolidated firms, once the companies that disappeared during the first years were eliminated from the initial sample. All firms were created during the first decade of this century in the Autonomous Community of Valencia of Spain and belong to several manufacturing and service industries.

\subsection{Configurational analysis}

Qualitative Comparative Analysis methods, such as the fuzzy-set Qualitative Comparative Analysis try to explain a particular result from the combination of antecedent conditions. These methods are opposed to those of a quantitative nature, such as the multivariate analysis that treat each variable as independent and analytically different and separate from the rest, which makes it difficult to analyse and interpret the results when there are interactions between different variables. In fact, it is the complex interactions between different conditions which tend to have a greater impact on the result (Schneider et al., 2010).

Qualitative Comparative Analysis methods have become a useful tool used in the field of social sciences and, particularly, in entrepreneurship and innovation research (Kraus et al., 2018). This family of methods is case-driven rather than variable-driven, which facilitates formal and systematic analysis of causality.

Qualitative Comparative Analysis studies the cases as configurations (combinations of conditions), causally relevant and an outcome. In this research, the antecedent conditions considered are: initial staff, initial capital, social interest, experience and training of the entrepreneur, motivation to undertake and industry. On the other hand, the outcome is firm survival. Table 1 shows the way in which they have been measured.

Each causal configuration constitutes a specific combination of causally relevant ingredients linked to an outcome (Ragin, 2008b, p. 9). This approach is based on the idea that causal relationships can often be better understood in terms of relationships between theoretical sets rather than correlations, as is the case with regression-based analysis (Fiss, 2007; Ragin, 2008a; Ragin \& Fiss, 2008). This methodology has advantages, because, firstly, it allows analysing all the possible combinations of antecedent conditions to test if all, or only a portion of the causal conditions, are related to the outcome. Secondly, it allows to know how those relevant conditions should be combined. Bearing in mind that the propositions enunciated in this research involve the existence of complex interactions between the different causal antecedents and raise the possibility that different configurations (causal patterns) may lead to the same outcome, the fuzzy-set Qualitative Comparative Analysis has been selected to test them.

Researchers have employed the software fuzzy-set Qualitative Comparative Analysis 2.5 for the analysis of the results (Ragin \& Davey, 2014). The works of Fiss (2011), Woodside (2012) and Feurer et al. (2016) illustrate the effectiveness of fuzzy-set Qualitative Comparative Analysis with large samples, which enables us to use it in this research.

This methodology captures the idea of equifinality (Fiss, 2011), since it admits that different conditions can lead to the same result and that the causal configurations that explain a given result may not coincide with those that explain the opposite result (Fiss, 2007, 2011; Ragin, 2008a; Ragin \& Fiss, 2008; Schneider et al., 2010; Woodside \& Zhang, 2013). In addition, it adopts the perspective that a simple condition may be necessary but will rarely be 
Table 1. Description of antecedent conditions

\begin{tabular}{|c|c|}
\hline Antecedent condition & Description \\
\hline Initial staff (plant) & $\begin{array}{l}\text { Total number of stable employees, including entrepreneurs or promoters } \\
\text { (full-time average initial staff) }\end{array}$ \\
\hline Initial capital (kin) & $\begin{array}{l}\text { Proxy of the initial capital, eligible capital according to the criteria of the } \\
\text { Valencian Institute of Youth }\end{array}$ \\
\hline Social interest (social) & $\begin{array}{l}\text { Dichotomous variable: } 1=\text { The firm has a social interest (purpose) } \\
\text { according to the criteria of the Valencian Institute of Youth; } 0=\text { The firm } \\
\text { doesn't have a social interest (purpose) according to the criteria of the } \\
\text { Valencian Institute of Youth }\end{array}$ \\
\hline $\begin{array}{l}\text { Related experience } \\
\text { (relexp) }\end{array}$ & $\begin{array}{l}\text { Categorical variable that indicates whether the entrepreneur has specific } \\
\text { related work experience. Its values are: } 1=\text { related; } 2=\text { semi-related; } 3=\text { not } \\
\text { related }\end{array}$ \\
\hline $\begin{array}{l}\text { Related training } \\
\text { (reltrain) }\end{array}$ & $\begin{array}{l}\text { Categorical variable that indicates if the entrepreneur has some type of } \\
\text { specific related training. Its values are: } 1=\text { related; } 2=\text { semi-related; } 3=\text { not } \\
\text { related }\end{array}$ \\
\hline $\begin{array}{l}\text { Motivation to } \\
\text { undertake (motiv) }\end{array}$ & $\begin{array}{l}\text { Dichotomous variable: } 1=\text { opportunity entrepreneurship; } 0=\text { necessity } \\
\text { entrepreneurship }\end{array}$ \\
\hline Industry (service) & Dichotomous variable: $1=$ services; $0=$ industry \\
\hline $\begin{array}{l}\text { New firms' survival } \\
(\text { surv } t+3)\end{array}$ & $\begin{array}{l}\text { Dichotomous variable: } 1=\text { After } 3 \text { years since the constitution, the } \\
\text { company survives; } 0=\text { After } 3 \text { years since the constitution, the company } \\
\text { has disappeared }\end{array}$ \\
\hline $\begin{array}{l}\text { Consolidated firms } \\
\text { survival (surv } t+6)\end{array}$ & $\begin{array}{l}\text { Dichotomous variable: } 1=\text { After } 6 \text { years since the constitution, the } \\
\text { company survives; } 0=\text { After } 6 \text { years since the constitution, the company } \\
\text { has disappeared }\end{array}$ \\
\hline
\end{tabular}

sufficient to cause a particular result. Thus, a certain combination of conditions is sufficient if it invariably, or almost invariably, leads to a certain result. In turn, a condition is necessary if it is present in all the causal configurations that explain a given result. Both conditions and configurations should be valued in terms of consistency and coverage (Kuckertz et al., 2015).

In order to execute the fuzzy-set Qualitative Comparative Analysis, first of all, the calibration of the original data (both the conditions and the result) must be carried out, that is, transformed into fuzzy-set membership scores (Fernandes-Crespo, 2017; Ragin, 2008a). Secondly, a necessity analysis must be carried out to check if the causal conditions are necessary for a certain outcome to be given. In this case, the value of consistency will be taken into account. Following Schneider et al. (2010), a minimum consistency threshold of 0.9 has been defined to consider a condition as necessary. Likewise, a consistency threshold of 0.8 has been established to consider a condition as sufficient, above that recommended by Ragin (2008a) of 0.75 . Only those configurations that present more than 4 cases are considered. These consistency scores are analogous to the correlations estimated in the traditional quantitative statistical analysis.

The next step is the construction of the truth table for each result (Fernandes-Crespo, 2017). It contains all the logically possible configurations of antecedent conditions, identifying the cases that each combination presents. With this, the researcher is able to identify those logically possible patterns that lead and do not lead to the result under study. 


\subsection{Original data calibration}

For the calibration of the data, authors followed the procedure established by Ragin (2008a). Fuzzy-set scores range from 0.00 (full non-membership) to 1.00 (full membership). Those scores are not probabilities, but a truth value. Between these two points ( 0 and 1$)$ it is necessary to establish, considering the theoretical grounds and the previous evidence, three cut-off points or observation points for each condition or result: the threshold for full membership, the threshold for full non-membership and the crossover point. The crossover point is the value of the interval-scale variable where there is maximum ambiguity as to whether a case is more in or more out of the target set (Ragin, 2008b, p. 90). In the study presented here, these values are $0.95,0.5$ and 0.05 , respectively. When the variables are dichotomous it is not necessary to establish these cut-off points.

Calibration assesses the extent to which cases meet or belong to a recipe or causal pattern. A case's membership score, in the case of a configuration formed by several causal conditions, constitutes the degree of membership in the intersection of the fuzzy-set causal conditions that comprise the recipe. This intersection value equals the minimum score among the conditions in the causal recipe using the calibrated values (Woodside \& Zhang, 2013: 269). Table 2 shows the cut-off points previously indicated, for all the conditions and the results analysed.

Table 2. Calibration of antecedent conditions and outcomes

\begin{tabular}{|c|c|c|c|}
\hline Antecedent condition & $\begin{array}{c}0.05 \\
\text { (Full non-membership) }\end{array}$ & $\begin{array}{c}0.5 \\
\text { (Crossover point) }\end{array}$ & $\begin{array}{c}0.95 \\
\text { (Full membership) }\end{array}$ \\
\hline Plant & 1 & 2.1 & 4 \\
\hline Kin & 4,103 & 19,158 & 79,413 \\
\hline Social & 0 & & $1=1$ \\
\hline Relexp & $3=0$ & $2=0.6$ & $1=1$ \\
\hline Reltrain & $3=0$ & $2=0.6$ & 1 \\
\hline Motiv & 0 & & 1 \\
\hline Service & 0 & & 1 \\
\hline Surv $\mathrm{t}+3$ & 0 & & \\
\hline Surv $\mathrm{t}+6$ & 0 & & \\
\hline
\end{tabular}

The following section presents the results of the necessity and sufficiency analysis, obtained by applying the algorithm used by the fuzzy-set Qualitative Comparative Analysis 2.5 to the calibrated data.

\section{Results}

\subsection{Descriptive analysis}

The descriptive analysis of the sample shows the following results. $73.7 \%$ are service firms and $26.3 \%$ are manufacturing companies. Only $9.9 \%$ of the firms can be considered with a social interest (purpose) according to the Valencian Institute of Youth criteria. $57.9 \%$ can 
be considered opportunity entrepreneurship while $42.1 \%$ are necessity entrepreneurships. $61.9 \%$ of the firms have at least one entrepreneur with related training, $4.6 \%$ semi-related and the remaining $33.5 \%$ do not have any related training. In terms of experience, $71 \%$ of the enterprises have at least one entrepreneur with related experience of more than one year, $4.0 \%$ have more than one year of semi-related experience and the remaining $25 \%$ do not have significant related experience. The staff ranges from 1 to 34 employees, with an average of 1.93 employees, so they are very small companies. The eligible investment, proxy of initial capital, varies from 1,000 Euros to a maximum of 1,200,000 Euros, with an average eligible investment of 35,022.07 Euros.

The necessity analysis is shown in Table 3. According to Ragin (2008a) and Schneider et al. (2010), if the consistency value of the causal condition is greater than 0.90 the condition is necessary and if the value is above 0.80 the condition is quasi-necessary. As shown in Table 3, some of the causal antecedents analysed, the fact of being a commercial firm (non-social entrepreneurship), and the fact of being a manufacturing entrepreneurship (not a service firm), are especially relevant in both periods $(t+3$ and $t+6)$. This allows us to define them as quasi-necessary conditions. It can be affirmed that, strictly speaking, none of the causal antecedents, by itself, constitutes a necessary condition for firm survival. Consequently, proposition \#1 is fulfilled. Nevertheless, it seems that survival is more likely in the case of commercial and manufacturing firms.

Table 3. Analysis of necessity for survival in $t+3$ (new firms) and $t+6$ (consolidated firms)

\begin{tabular}{|l|c|c|c|c|}
\hline \multicolumn{1}{|c|}{ Outcome $\rightarrow$} & \multicolumn{2}{c|}{ surv_t +3} & \multicolumn{2}{c|}{ surv_t + 6 } \\
\hline Conditions & Consistency & Coverage & Consistency & Coverage \\
\hline fs_plant & 0.359630 & 0.824108 & 0.384802 & 0.706185 \\
\hline$\sim$ fs_plant & 0.640370 & 0.699522 & 0.615198 & 0.538194 \\
\hline fs_kin & 0.493167 & 0.780842 & 0.510876 & 0.647795 \\
\hline$\sim$ fs_kin & 0.506833 & 0.703698 & 0.489124 & 0.543868 \\
\hline social & 0.100047 & 0.727586 & 0.105388 & 0.613793 \\
\hline$\sim$ social & $\mathbf{0 . 8 9 9 9 5 3}$ & 0.741117 & $\mathbf{0 . 8 9 4 6 1 2}$ & 0.590004 \\
\hline fs_relexp & 0.755714 & 0.762292 & 0.777975 & 0.628468 \\
\hline$\sim$ fs_relexp & 0.244286 & 0.677716 & 0.222025 & 0.493291 \\
\hline fs_reltrain & 0.675296 & 0.772762 & 0.704204 & 0.645361 \\
\hline$\sim$ fs_reltrain & 0.324704 & 0.679365 & 0.295796 & 0.495635 \\
\hline motiv(oport) & 0.457089 & 0.803333 & 0.493783 & 0.695000 \\
\hline$\sim$ motiv(oport) & 0.542911 & 0.693519 & 0.506217 & 0.517868 \\
\hline service & 0.182551 & 0.795455 & 0.190645 & 0.665289 \\
\hline$\sim$ service & $\mathbf{0 . 8 1 7 4 4 9}$ & 0.728348 & $\mathbf{0 . 8 0 9 3 5 5}$ & 0.577524 \\
\hline
\end{tabular}

Note: fs_indicates presence of the condition and $\sim \mathrm{fs} \_$indicates absence of the condition.

With regard to the sufficiency analysis, that was presented below, it should be noted that the most parsimonious solutions have been collected. In this solution any combination that 
does not present empirical evidence is incorporated into the reduction process, but incorporates all the logical remainders, thus providing a more easily analysable solution (Ragin, 2008a). Section 3.2 presents the results for the new firms and section 3.3 for the consolidated ones.

\subsection{Results for survival at $t+3$}

Table 4 shows the different causal configurations that lead firms to survival in the period $t+3$. The model presents a global consistency of 0.84 , which implies a good level of consistency according to Ragin (2008a) and explain approximately 35\% of the cases (global coverage). Solution 1 has a consistency score lower than 0.75 , so it will not be taken into consideration in the detailed analysis of the survival patterns.

With respect to the interpretation of the causal configurations, it could be highlighted that two out of the seven conditions (i.e., initial capital and motivation to undertake by opportunity) are present in 4 of the configurations. This result reveals the importance of having a high initial capital to overcome possible financial problems in the first years of the business. Likewise, the motivation to set up a business based on an opportunity is a result consistent with the specialist literature (Headd, 2003; Ho \& Wong, 2007; Rico-Belda \& Cabrer-Borrás, 2018; Van Praag, 2003), based this fact on the resilience of those who have an entrepreneurial vocation and their tendency to be more innovative (Simón-Moya et al., 2014).

Table 4. Most parsimonious solution for survival at $t+3$

\begin{tabular}{|c|c|c|c|c|c|c|c|c|c|c|}
\hline \multirow{2}{*}{ ن } & \multicolumn{7}{|c|}{ Antecedent conditions } & \multirow[b]{2}{*}{$\begin{array}{c}\text { Gross } \\
\text { coverage }\end{array}$} & \multirow[b]{2}{*}{$\begin{array}{l}\text { Net or specific } \\
\text { coverage }\end{array}$} & \multirow[b]{2}{*}{ Consistency } \\
\hline & 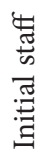 & 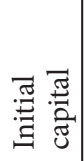 & 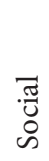 & 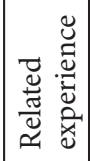 & 总 & 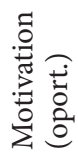 & 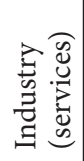 & & & \\
\hline 1 & & & O & $\mathrm{O}$ & & & & 0.019725 & 0.013310 & 0.640000 \\
\hline 2 & & & & & 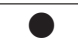 & & 0 & 0.090944 & 0.061678 & 0.872611 \\
\hline 3 & O & O & O & & & & & 0.028639 & 0.009331 & 0.846768 \\
\hline 4 & & 0 & & & 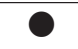 & 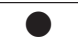 & & 0.167549 & 0.051679 & 0.869061 \\
\hline 5 & O & O & & O & & 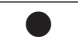 & & 0.022665 & 0.009891 & 0.746875 \\
\hline 6 & O & & & 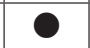 & & 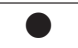 & & 0.142081 & 0.046097 & 0.885309 \\
\hline 7 & O & O & & 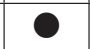 & & 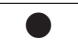 & & 0.130962 & 0.015676 & 0.877746 \\
\hline \multicolumn{11}{|c|}{ Coverage of the solution: 0.348653} \\
\hline \multicolumn{11}{|c|}{ Consistency of the solution: 0.845924} \\
\hline
\end{tabular}

Note: Black circles "O" indicate the presence of an antecedent condition. White circles " $\bigcirc$ " indicate the absence or negation of an antecedent condition. Blank cells represent ambiguous conditions. Frequency threshold $=5$; Consistency threshold $=0.80$.

The configurations with the greatest coverage are 4 (0.168), $6(0.142)$ and 7 (0.131). Configuration 7 indicates that new firms with larger staff, which are undertaken by opportunity, with experienced entrepreneurs and that have a high initial capital, have a higher probability of survival at $t+3$. In turn, configuration 6 explains the same result based on the combina- 
tion of three antecedents: a large staff, related experience of entrepreneur and motivation based on opportunity. Finally, configuration 4 indicates that if the initial capital is relatively high, the entrepreneur has related training and the motivation to undertake is based on opportunity, the probability of survival at $t+3$ increases. As shown in Table 4 , the social nature of entrepreneurship and related training are factors that appear least in the analysed configurations. Contrarily, a higher initial capital, a large workforce or the fact that the firm is undertaken by opportunity, are the most common. Consequently, the likelihood for companies of surviving without these factors decreases, as they are especially difficult to be replaced.

Finally, it is striking that related training and experience, considered in the specialised literature as key factors for entrepreneurship success (Headd, 2003; Millan et al., 2012), do not play a more important role for new firm's survival. Nevertheless, in early stages of the venture, where novelty and smallness may become significant inhibitors, the available capital could be key to survival in the short term (Revuelto-Taboada \& Simón-Moya, 2015) and more important than the related experience and training of the entrepreneur. This capital will allow the entrepreneur to acquire necessary resources, make basic investments and wipe away the first losses.

\subsection{Results for survival at $t+6$}

Table 5 includes the causal configurations that explain survival in the period $t+6$. These results explain $51.5 \%$ of the cases. The overall consistency of 0.86 as well as the consistency of each of the causal patterns or conditions is above 0.8 . As it can be seen, opportunity motivation, related training and initial capital are in 3 of the 6 configurations obtained. The configurations that offer the highest gross coverage are $2(0.253), 4(0.230)$ and $5(0.208)$, although considering the net coverage the configuration 3 would be at the same level as configuration 2. In configuration 2, a high initial staff in an opportunity entrepreneurship seems to increase the chances of survival of consolidated firms. In configuration 4, a high initial capital, related experience and opportunity motivation explain survival. Last, high initial capital, related experience and training, as well as a small staff, are the factors that explain survival in consolidated firms according to configuration 5.

As can be observed, initial capital keeps on playing an important role in consolidated firms' survival, especially in combination with factors associated with the entrepreneur's background (related experience and training) and opportunity motivation. However, it could be also noted that, unlike the patterns at $t+3$, there are firms at $t+6$ that manage to survive in the absence of a high initial capital but with a high related training and an opportunity entrepreneurship (configuration 3). In turn, configuration 1 includes social entrepreneurship and a large staff to explain the survival of consolidated firms, although the coverage value is very low.

These results show differences between the causal patterns that explain new firms' and consolidated firm's survival. This fact becomes an evidence in favour of proposition \#2. Although there is no combination that is exactly the same in the two periods, there are combinations between which there are many similarities (i.e., configuration 2 at $\mathrm{t} 3$ and configuration 6 at $\mathrm{t}+6$; configuration 7 at $\mathrm{t}+3$ and configuration 4 at $\mathrm{t}+6$ ). 
Table 5. Most parsimonious solution for survival at $\mathrm{t}+6$

\begin{tabular}{|c|c|c|c|c|c|c|c|c|c|c|}
\hline \multirow[b]{2}{*}{ ن } & \multicolumn{7}{|c|}{ Antecedent conditions } & \multirow[b]{2}{*}{$\begin{array}{l}\text { Gross } \\
\text { coverage }\end{array}$} & \multirow[b]{2}{*}{$\begin{array}{l}\text { Net or specific } \\
\text { coverage }\end{array}$} & \multirow[b]{2}{*}{ Consistency } \\
\hline & 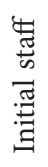 & 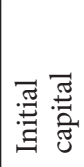 & $\begin{array}{l}. \bar{J} \\
\text { d } \\
\dot{0}\end{array}$ & 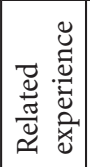 & 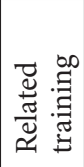 & 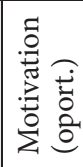 & 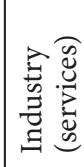 & & & \\
\hline 1 & O & & O & $\mathrm{O}$ & & & & 0.050216 & 0.015865 & 0.862332 \\
\hline 2 & O & & & & & 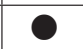 & & 0.253202 & 0.049213 & 0.888096 \\
\hline 3 & & 0 & & & 0 & O & & 0.166172 & 0.049249 & 0.836667 \\
\hline 4 & & O & & O & & O & & 0.230433 & 0.033972 & 0.881897 \\
\hline 5 & O & O & & 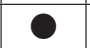 & 0 & & & 0.207609 & 0.088312 & 0.844748 \\
\hline 6 & & - & & & 0 & & O & 0.054952 & 0.008636 & 0.910213 \\
\hline \multicolumn{11}{|c|}{ Coverage of the solution: 0.348653} \\
\hline 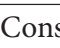 & & & & 08 & & & & & & \\
\hline
\end{tabular}

Note: Black circles " indicate the presence of an antecedent condition. White circles " $\bigcirc$ " indicate the absence or negation of an antecedent condition. Blank cells represent ambiguous conditions. Frequency threshold $=5$; Consistency threshold $=0.80$.

Initial capital and opportunity motivation remain the most remarkable factors, although within the framework of significantly different combinations. Over time, related training become a more relevant factor in those patterns that could be called winning combinations. However, if the arguments of Revuelto-Taboada and Simón-Moya (2015) are born in mind a more relevant change in relative importance would be expected, especially in the service sector, between the impact of having a high initial capital and a large staff, and having related experience and training. Therefore, there is limited evidence in favour of proposition \#3.

\section{Discussion}

The main objective of this research has been to analyse the causal complexity underlying the survival of entrepreneurial initiatives, both in new and consolidated companies. The vast majority of previous studies devoted to analysing survival of companies have employed multivariate statistical techniques. Consequently, their contribution is very poor in relation to the possible interactions between explanatory or conditioning variables. On the contrary, the use of Qualitative Comparative Analysis allows us to observe the joint effect of different combinations of causal antecedents, which is a contribution of this work.

As expected, there is no single pattern for firm survival in $t+3$ or $t+6$, that is, for new and consolidated firms. Nevertheless, the results obtained reveal interesting patterns in both cases. First of all, they reveal the importance of having an initial capital that allow the new firms to overcome the shortcomings or disadvantages suffered when entering the industry (Cafferata et al., 2009). Likewise, it has been shown that opportunity entrepreneurships have a greater chance of survival, since these vocational entrepreneurs are more committed, have lower aversion to risk, tend to be more trained and are more innovative. This result is consistent with the specialist literature (Headd, 2003; Ho \& Wong, 2007; Simón-Moya et al., 2014). 
Related training and experience are also shown as relevant variables, which is consistent with previous research (Korunka et al., 2010; Ribeiro-Soriano \& Castrogiovanni, 2012). Conversely, the fact of being a social firm with a social interest does not seem to facilitate survival, but there is no clear evidence that this factor blocks survival. Thus, results for and against a greater survival of social entrepreneurships obtained in prior studies (e.g., Denny, 2014; Simón-Moya et al., 2012) could be caused by other factors that do not have to do, strictly, with their condition (or not) of being social enterprises.

Although there are differences in terms of winning combinations in the case of new and consolidated firms these divergences are lower than expected, particularly with respect to the role of the initial staff and the related experience. More than likely, the limitations of the sample in terms of the low dispersion of size and the age of the entrepreneurs, as well as the impossibility of considering a longer period, are behind these results.

In any case, the existence of several sufficient solutions that, in addition, vary slightly according to the period considered (i.e., $t+3$ or $t+6$ ), leads us to conclude that there is no a best way to survive and that the relative importance of the different antecedent conditions may vary as the company becomes more mature. These different configurations also seem to indicate that the absence of a certain characteristic or the lack of a particular resource can, in a certain way, be compensated by the presence of others. Thus, for example, results reveal that if a high initial capital is combined with an important related experience and an opportunity-based motivation to set up the business, the chances of survival increase. But also, without so many financial resources but with a larger staff and the same kind of motivation, survival probabilities also increase. Or, with scarce initial capital but adequate related training, survival chances increase in the service sector.

\section{Conclusions}

The results of this research may offer practical guides to those responsible for public policies aimed at the promotion of entrepreneurship. In this sense, the results obtained reveal that opportunity motivation arises as a relevant condition to explain the survival of entrepreneurships as far as it is present in many of the identified causal configurations. If it is added that opportunity entrepreneurship positively impacts the economic development of nations as it facilitates higher rates of growth and innovation, prioritizing and promoting it may turn out to be strategic for governments.

Likewise, it has been shown how certain objective variables (i.e., initial capital, related training and experience and size in terms of staff), through different combinations, have an impact on entrepreneurship survival. Taking this into account, the evaluation of public aid requests, especially financial ones, should consider to a greater extent objective and easyto-assess variables as those mentioned above, and not mainly the viability of the project reported. In many cases, this report is more a declaration of intent that has been written purposely to get the funds and not a true road map for the company. Even if the project is viable, failure is practically guaranteed if the necessary initial human and financial capital is not available. On the other hand, according to the results obtained it could be stated that the social or hybrid nature of entrepreneurship does not affect negatively its chances of survival. 
Consequently, it would be a priority to promote this type of initiatives since they can generate social benefits, as well as employment and wealth.

In addition, results obtained show the importance of related training and experience for survival, which leads us to insist on the need to boost training activities, especially when they own a theoretical-practical nature and are related to the activity that is intended to be undertaken. Bearing this in mind, authors believe that some public initiatives aimed at promoting entrepreneurship and self-employment should be given greater prominence. For example, other types of programmes more focused on prior advice and follow-up after the constitution of the firm could make an important contribution to entrepreneurship and society. These programmes, which may or may not be linked to the achievement of financial aid, could be very effective in increasing the probabilities of success of new firms, as they could help to complete the initial training of entrepreneurs and supplement, at least in a first stage, the lack of experience and some of their shortcomings in managerial skills. The promotion of partnership and inter-firm cooperation, with the support of public and private institutions, can also constitute another way to overcome the aforementioned shortcomings. On the other hand, when it comes to evaluate applications for financial public aids, it seems advisable to take great account, in addition to the employment generated and firm social character, which can generate social benefits, objective and easy-to-evaluate variables such as initial capital and training and related experience and fewer business plans that, in most cases, have few glimpses of becoming a reality.

This research presents some limitations. First of all, this study uses data from entrepreneurs under 30 years, alone or accompanied by older entrepreneurs, who start businesses in the Community of Valencia and who have a small workforce. This fact limits the possibility of generalisation. So, it would be convenient in future research to replicate the research in different regions and countries, with a sample that encompasses entrepreneurs of different ages and firms with a greater diversity of sizes. With this, related experience and initial staff could play a more determining role in explaining survival. Furthermore, studies conducted in various countries presenting significantly different socio-economic and institutional contexts could allow to analyse the effect of these variables on business survival patterns.

Secondly, the impossibility of establishing the specific date of firm's closure may also have limited the analysis of those variables affecting survival. Likewise, the impossibility of distinguishing in this work between closure and failure, which are not always synonyms, could have introduced some bias in the results obtained. Also, possible changes in the composition of the entrepreneurial team and in the rest of causal factors which were measured at the start of the activity of the company have not been considered. Its consideration should be especially important in studies that comprise a long period of analysis.

Finally, another limitation that has surely reduced the explanatory capacity of the model has to do with the fact of not having considered other potentially relevant variables, such as the phase of the economic cycle in which the companies studied begin their activity, the particularities of their activity sector, their competitive strategy or the gender and the psychological characteristics of the entrepreneur. These variables should be taken into account in future research. For example, longitudinal studies would allow us to analyse how changes in economic cycle, substantial changes in the human, financial and physical capital 
endowment of companies or in their network of cooperation relations, could affect business survival patterns.

\section{Acknowledgements}

Authors are very grateful to the staff of the Program Management and Planning Service of Valencian Institute of Youth, and especially to Mrs. Silvia Albert Guardiola. Authors also thank Norat Roig-Tierno for his advice on methodological issues.

\section{Funding}

This work was supported by the University of Valencia under Grant UV-INV-AE19-1200085.

\section{Author contributions}

LRT conceived the study and was responsible for the development of the theoretical background, the fieldwork, the methodology, the interpretation of results and preparation of the original draft. ARC and FBB contributed to the theoretical background, data analysis, drawing conclusions and preparation of the original draft. LRT, ARC and FBB were responsible for funding acquisition, revising the original draft and preparing the final version.

\section{Disclosure statement}

Authors declare that do not have any competing financial, professional or personal interests from other parties.

\section{References}

Agarwal, R., \& Audretsch, D. B. (2001). Does entry size matter? The impact of the life cycle and technology on firm survival. Journal of Industrial Economics, 49(1), 21-43. https://doi.org/10.1111/1467-6451.00136

Aghion, P. (2011). Industrial policy, entrepreneurship and growth. In D. B. Audstrech, O. Falck, S. Heblich, \& A. Lederer (Eds.), Handbook of research on innovation and entrepreneurship (pp. 45-54). Edward Elgar Publishing. https://doi.org/10.4337/9781849807760.00012

Brüderl, J., \& Schüssler, R. (1990). Organizational mortality: The liabilities of newness and adolescence. Administrative Science Quarterly, 35(3), 530-537. https://doi.org/10.2307/2393316

Cafferata, R., Abatecola, G., \& Poggesi, S. (2009). Revisiting Stinchcombe’s "liability of newness": A systematic literature review. International Journal of Globalization and Small Business, 3(4), 374-392. https://doi.org/10.1504/IJGSB.2009.032258

Carlsson, B., Braunerhjelm, P., McKelvey, M., Olofsson, Ch., Persson, L., \& Ylinenpää, H. (2013). The evolving domain of entrepreneurship research. Small Business Economics, 41(4), 913-930. https://doi.org/10.1007/s11187-013-9503-y

Chadwick, I. C., \& Raver, J. L. (2020). Psychological resilience and its downstream effects for business survival in nascent entrepreneurship. Entrepreneurship Theory and Practice, 44(2), 233-255. https://doi.org/10.1177/1042258718801597 
Chandra, Y., \& Wong, L. (2016). Social entrepreneurship in the Greater China region: Policy and cases ( $1^{\text {st }}$ ed.). Routledge. https://doi.org/10.4324/9781315670065

Denny, S. (2014). Who lives the longest? Busting the social venture survival myth. E3M. http://socialbusinessint.com/wp-content/uploads/Who-lives-the-longest_-FINAL-version2.pdf

Di Domenico, M., Haugh, H., \& Tracey, P. (2010). Social bricolage: Theorizing social value creation in social enterprises. Entrepreneurship Theory and Practice, 34(4), 681-703. https://doi.org/10.1111/j.1540-6520.2010.00370.x

Dimov, D. (2017). Towards a qualitative understanding of human capital in entrepreneurship research. International Journal of Entrepreneurial Behaviour and Research, 23(2), 210-227. https://doi.org/10.1108/IJEBR-01-2016-0016

El Harbi, S., \& Anderson, A. R. (2010). Institutions and the shaping of different forms of entrepreneurship. The Journal of Socio-Economics, 39(3), 436-444. https://doi.org/10.1016/j.socec.2010.02.011

Eliakis, S., Kotsopoulos, D., Karagiannaki, A., \& Pramatari, K. (2020). Survival and growth in innovative technology entrepreneurship: A mixed-methods investigation. Administrative Sciences, 10(3), 39. https://doi.org/10.3390/admsci10030039

Fernandes-Crespo, N. (2017). Cross-cultural differences in the entrepreneurial activity of men and women: A fuzzy-set approach. Gender in Management: An International Journal, 32(4), 281-299. https://doi.org/10.1108/GM-03-2016-0072

Feurer, S., Baumbach, E., \& Woodside, A. G. (2016). Applying configurational theory to build a typology of ethnocentric consumers. International Marketing Review, 33(3), 351-375. https://doi.org/10.1108/IMR-03-2014-0075

Fiss, P. C. (2007). A set-theoretic approach to organizational configurations. The Academy of Management Review, 32(2), 1180-1198. https://doi.org/10.5465/amr.2007.26586092

Fiss, P. C. (2011). Building better causal theories: A fuzzy set approach to typologies in organization research. Academy of Management Journal, 54(2), 393-420. https://doi.org/10.5465/amj.2011.60263120

Fournier, A. N. (2011). Emprendimiento Social. Documentos de investigación. Administración de Empresas, No 6, 1-46. https://papers.ssrn.com/sol3/papers.cfm?abstract_id=2016601

Franco, M., \& Haase, H. (2010). Failure factors in small and medium-sized enterprises: Qualitative study from an attributional perspective. International Entrepreneurship and Management Journal, 6(4), 503-521. https://doi.org/10.1007/s11365-009-0124-5

Garud, R., \& Karnoe, P. (2003). Bricolage versus breakthrough: Distributed and embedded agency in technology entrepreneurship. Research Policy, 32(2), 277-300. https://doi.org/10.1016/S0048-7333(02)00100-2

Gimmon, E., \& Spiro, S. (2013). Social and commercial ventures: A comparative analysis of sustainability. Journal of Social Entrepreneurship, 4(2), 182-197. https://doi.org/10.1080/19420676.2013.777359

Grant, A. M. (2008). Does intrinsic motivation fuel the prosocial fire? Motivational synergy in predicting persistence, performance and productivity. Journal of Applied Psychology, 93(1), 48-58. https://doi.org/10.1037/0021-9010.93.1.48

Guzmán, A., \& Trujillo, M. A. (2008). Emprendimiento social. Revisión de literatura. Estudios Gerenciales, 24(109), 105-125. https://doi.org/10.1016/S0123-5923(08)70055-X

Haber, S., \& Reichel, A. (2005). Identifying performance measures of small ventures - the case of the tourism industry. Journal of Small Business Management, 43(3), 257-286. https://doi.org/10.1111/j.1540-627X.2005.00137.x

Headd, B. (2003). Redefining business success: Distinguishing between closure and failure. Small Business Economics, 21(1), 51-61. https://doi.org/10.1023/A:1024433630958

Ho, Y., \& Wong, P. (2007). Financing, regulatory costs and entrepreneurial propensity. Small Business Economics, 28(2), 187-204. https://doi.org/10.1007/s11187-006-9015-0 
Kelley, D., Bosma, N., \& Amorós, J. E. (2010). Global entrepreneurship monitor. Retrieved May 20, 2013, from http://www.gemconsortium.org/docs/download/266

Kerr, W., \& Nanda, R. (2011). Financing constraints and Entrepreneurship. In D. Audretsch, O. Falck, S. Heblich, \& A. Lederer (Eds.), Handbook on research on Innovation and Entrepreneurship (pp. 88103). Edward Elgar Publishing.

Korunka, C., Kessler, A., Frank, H., \& Lueger, M. (2010). Personal characteristics, resources, and environment as predictors of business survival. Journal of Occupational and Organizational Psychology, 83(4), 1021-1051. https://doi.org/10.1348/096317909X485135

Kraus, S., Ribeiro-Soriano, D., \& Schüssler, M. (2018). Fuzzy-set qualitative comparative analysis (fsQ$\mathrm{CA}$ ) in entrepreneurship and innovation research - the rise of a method. International Entrepreneurship and Management Journal, 14(1), 15-33. https://doi.org/10.1007/s11365-017-0461-8

Kuckertz, A., Berger, E., \& Allmendinger, M. (2015). What drives entrepreneurship? A configurational analysis of the determinants of entrepreneurship in innovation-driven economies. Die Betriebswirtschaft, 75(4), 273-288. https://ssrn.com/abstract=2554944

Kurczewska, A., \& Mackiewicz, M. (2020). Are jacks-of-all-trades successful entrepreneurs? Revisiting Lazear's theory of entrepreneurship. Baltic Journal of Management, 15(3), 411-430. https://doi.org/10.1108/BJM-07-2019-0274

Martínez-Rodriguez, I., Callejas-Albiñana, F. E., \& Callejas-Albiñana, A. I. (2020). Economic and sociocultural drivers of necessity and opportunity entrepreneurship depending on the business cycle phase. Journal of Business Economics and Management, 21(2), 373-394.

https://doi.org/10.3846/jbem.2020.11848

Mas-Verdú, F., Ribeiro-Soriano, D., \& Roig-Tierno, N. (2015). Firm survival: The role of incubators and business characteristics. Journal of Business Research, 68(4), 793-796.

https://doi.org/10.1016/j.jbusres.2014.11.030

Millan, J. M., Congregado, E., \& Román, C. (2012). Determinants of self-employment survival in Europe. Small Business Economics, 38(2), 231-258. https://doi.org/10.1007/s11187-010-9260-0

Nicolás, C., \& Rubio, A. M. (2012). El emprendimiento social: una comparativa entre España y países sudamericanos. FAEDYPE International Review, 1(1), 38-49.

http://www.viiaccountingworkshop.upct.es/index.php/revista1/article/viewFile/13/4

Nyström, K. (2020). Entrepreneurship after displacement. Small Business Economics, 54(2), 475-494. https://doi.org/10.1007/s11187-018-0045-1

Penner, L. A., Dovidio, J. F., Piliavin, J. A., \& Schroeder, D. A. (2005). Prosocial behavior: Multilevel perspectives. Annual Review of Psychology, 56(14), 1-28. https://doi.org/10.1146/annurev.psych.56.091103.070141

Ragin, C. C. (2008a). Measurement versus calibration: A set-theoretic approach. In J. J. Box-Steffensmeier, H. Brady, \& D. Collier (Eds.), The Oxford handbook of political methodology (pp. 174-198). Oxford University Press. https://doi.org/10.1093/oxfordhb/9780199286546.003.0008

Ragin, C. C. (2008b). Redesigning social inquiry: Fuzzy sets and beyond. Chicago University Press. https://doi.org/10.7208/chicago/9780226702797.001.0001

Ragin, C. C., \& Davey, S. (2014). Fuzzy-set/qualitative comparative analysis 2.5. Department of Sociology, University of California.

Ragin, C. C., \& Fiss, P. C. (2008). Net effects versus configurations: An empirical demonstration. In C. C. Ragin (Ed.), Redesigning social inquiry: Fuzzy sets and beyond (pp. 190-212). University of Chicago Press. https://press.uchicago.edu/ucp/books/book/chicago/R/bo5973952.html

Raine, A. L., \& Pandya, M. (2019). Three keys to entrepreneurial success: Curiosity, creativity, and commitment. Entrepreneurship Education, 2(3-4), 189-198.

https://doi.org/10.1007/s41959-019-00019-y 
Revuelto-Taboada, L., \& Simón-Moya, V. (2015). Influence of human and physical capital on the survival of new ventures. Perspectiva Empresarial, 2(1), 45-59. https://doi.org/10.16967\%2Frpe.v2n1a3

Ribeiro-Soriano, D., \& Castrogiovanni, G. (2012). The impact of CEO education, experience, and inner circle advisors on SME performance: Insights from a study in public development centers. Small Business Economics, 38(3), 333-349. https://doi.org/10.1007/s11187-010-9278-3

Rico-Belda, P., \& Cabrer-Borrás, B. (2018). Necessity and opportunity entrepreneurs: Survival factors. International Entrepreneurship and Management Journal, 14(2), 249-264. https://doi.org/10.1007/s11365-018-0504-9

Roberts, P. W., Negro, G., \& Swaminathan, A. (2013). Balancing the skills sets of founders: Implications for the quality of organizational outputs. Strategic Organization, 11(1), 35-55. https://doi.org/10.1177/1476127012460944

Salder, J., \& Bryson, J. R. (2019). Placing entrepreneurship and firming small town economies: Manufacturing firms, adaptive embeddedness, survival and linked enterprise structures. Entrepreneurship \& Regional Development, 31(9-10), 806-825. https://doi.org/10.1080/08985626.2019.1600238

Schneider, M. R., Schulze-Bentrop, C., \& Paunescu, M. (2010). Mapping the institutional capital of high-tech firms: A fuzzy-set analysis of capitalist variety and export performance. Journal of International Business Studies, 41(2), 246-266. https://doi.org/10.1057/jibs.2009.36

Schutjens, V. A. J. M., \& Wever, E. (2000). Determinants of new firm success. Papers in Regional Science, 79(2), 135-159. https://doi.org/10.1111/j.1435-5597.2000.tb00765.x

Senyard, J., Baker, T., Steffens, P., \& Davidsson, P. (2014). Bricolage as a path to innovativeness for resource-constrained new firms. Journal of Product Innovation Management, 31(2), 211-230. https://doi.org/10.1111/jpim.12091

Simón-Moya, V., \& Revuelto-Taboada, L. (2016). Revising the predictive capability of business plan quality for new firm survival using qualitative comparative analysis. Journal of Business Research, 69(4), 1351-1356. https://doi.org/10.1016/j.jbusres.2015.10.106

Simón-Moya, V., Revuelto-Taboada, L., \& Fernández-Guerrero, R. (2014). Institutional and economic drivers of entrepreneurship: An international perspective. Journal of Business Research, 67(5), 715721. https://doi.org/10.1016/j.jbusres.2013.11.033

Simón-Moya, V., Revuelto-Taboada, L., \& Ribeiro-Soriano, D. (2012). Are success and survival factors the same for social and business ventures? Service Business, 6(2), 219-242. https://doi.org/10.1007/s11628-012-0133-2

Stewart, S. A. (2018). Expert and entrepreneur: the unique research domain of professional service entrepreneurs. International Entrepreneurship and Management Journal, 14(3), 615-626. https://doi.org/10.1007/s11365-018-0516-5

Stinchcombe, A. L. (1965). Social structures and organizations. In J. G. March (Ed.), Handbook of organizations (pp. 142-193). Rand McNally.

Van Praag, C. M. (2003). Business survival and success of young small business owners. Small Business Economics, 21(1), 1-17. https://doi.org/10.1023/A:1024453200297

Woodside, A. G. (2012). Proposing a new logic for data analysis in marketing and consumer behavior: Case study research of large-N survey data for estimating algorithms that accurately profile X (extremely high-use) consumer. Journal of Global Scholars of Marketing Science: Bridging Asia and the World, 22(4), 277-289. https://doi.org/10.1080/21639159.2012.717369

Woodside, A. G., \& Zhang, M. (2013). Cultural diversity and marketing transactions: Are market integration, large community size, and world religions necessary for fairness in ephemeral exchanges? Psychology \& Marketing, 30(3), 263-276. https://doi.org/10.1002/mar.20603 